\title{
Bacterial secretion of soluble and functional trivalent scFv-based $\mathrm{N}$-terminal trimerbodies
}

\author{
Ana Blanco-Toribio ${ }^{1}$, Ana Álvarez-Cienfuegos ${ }^{2}$, Noelia Sainz-Pastor ${ }^{2}$, Nekane Merino ${ }^{3}$, Marta Compte ${ }^{1}$, \\ Laura Sanz ${ }^{2}$, Francisco J Blanco ${ }^{3,4}$ and Luis Álvarez-Vallina ${ }^{{ }^{*}}$
}

\begin{abstract}
Recombinant antibodies are used with great success in many different diagnostic and therapeutic applications. A variety of protein expression systems are available, but nowadays almost all therapeutic antibodies are produced in mammalian cell lines due to their complex structure and glycosylation requirements. However, production of clinical-grade antibodies in mammalian cells is very expensive and time-consuming. On the other hand, Escherichia coli (E. coli) is known to be the simplest, fastest and most cost-effective recombinant expression system, which usually achieves higher protein yields than mammalian cells. Indeed, it is one of the most popular host in the industry for the expression of recombinant proteins. In this work, a trivalent single-chain fragment variable (scFv)-based N-terminal trimerbody, specific for native laminin-111, was expressed in human embryonic kidney 293 cells and in E. coli. Mammalian and bacterially produced anti-laminin trimerbody molecules display comparable functional and structural properties, although importantly the yield of trimerbody expressed in E. coli was considerably higher than in human cells. These results demonstrated that $E$. coli is a versatile and efficient expression system for multivalent trimerbodybased molecules that is suitable for their industrial production.
\end{abstract}

Keywords: E. coli, Recombinant antibody, Multivalent antibody, Trimerbody

\section{Introduction}

Recombinant antibodies represent one of the fastest growing class of biopharmaceutical products and are established as important tools for research, diagnosis and therapy (Leavy 2010). First generation monoclonal antibodies (mAbs) have achieved considerable success in the treatment of a plethora of conditions including inflammation, autoimmune, cardiovascular and infectious diseases, and cancer (Reichert 2014). Next generation antibodies are designed to further increase the potency, improve the safety profile and acquire non-natural properties, and constitute a key area in the research and development of recombinant antibody (Nuñez-Prado

\footnotetext{
*Correspondence: lav@eng.au.dk

${ }^{5}$ Immunotherapy and Cell Engineering Laboratory, Department of Engineering, Aarhus University, Gustav Wieds Vej, 8000 Aarhus, Denmark

Full list of author information is available at the end of the article
}

et al. 2015). Currently, a diverse array of non-canonical antibody formats with modified architectures and additional functions has been generated (Cuesta et al. 2010; Nuñez-Prado et al. 2015). In parallel, a wide variety of production systems have been developed, ranging from bacteria (both Gram-negative and positive), yeasts, insect cell lines and mammalian cells to transgenic plants and animals (Frenzel et al. 2013).

We have recently reported the in vitro and in vivo properties of multivalent antibodies generated by fusing a trimerization (TIE) domain to the $\mathrm{N}$ - or C-terminus of a single-chain variable fragment (scFv) (Sánchez-Arevalo Lobo et al. 2006; Cuesta et al. 2009, 2012; Blanco-Toribio et al. 2013). TIE domains are composed of the N-terminal trimerization region of collagen XVIII NC1 (TIE ${ }^{\mathrm{XVIII}}$ ) or collagen XV NC1 ( $\mathrm{TIE}^{\mathrm{XV}}$ ) flanked by flexible linkers. This new antibody format, termed trimerbody, is trimeric in solution and exhibited excellent antigen binding capacity and multivalency (Sánchez-Arevalo Lobo et al.

\section{Springer}


2006; Cuesta et al. 2009, 2012). Furthermore, by fusing $\mathrm{scFv}$ antibodies with the same or different specificity to both ends of a TIE ${ }^{\mathrm{XVIII}}$ domain, we have produced monospecific or bispecific hexavalent-binding molecules, thereby expanding the scope of potential applications of trimerbody molecules (Blanco-Toribio et al. 2013). Due to their multimeric nature and the requirement of forming disulfide bonds for the generation of functional antigen-binding sites in the scFv domains, trimerbodies have been produced in eukaryotic cells until now, using yeast (Pichia Pastoris) and mammalian cells (Sánchez-Arevalo Lobo et al. 2006; Cuesta et al. 2009, 2012; Blanco-Toribio et al. 2013, 2014). However, nearly $30 \%$ of currently clinically approved recombinant therapeutic proteins are produced in Escherichia coli (Baneyx 1999; Huang et al. 2012) (Huang et al. 2012). The main reasons for this choice are cost-efficiency, well-characterized genetics, and the availability of a diverse molecular toolkit for genetic engineering (Makino et al. 2011; Overton 2014).

Here, we have studied the potential of $E$. coli for the production of $\mathrm{scFv}$-based $\mathrm{N}$-terminal trimerbodies using the anti-angiogenic scFv antibodies $\mathrm{L} 36$ and $2 \mathrm{H} 1$. The L36 scFv recognizes laminin-111, inhibits capillary morphogenesis of endothelial cells and prevents the establishment and growth of subcutaneous tumors in mice (Sanz et al. 2002; Sánchez-Arevalo Lobo et al. 2006), whereas the $2 \mathrm{H} 1 \mathrm{scFv}$ blocks the interaction between vascular endothelial growth factor (VEGF) and VEGF receptor-2 (KDR/Flk-1) and hampers endothelial cell proliferation in a dose-dependent manner (Lamdan et al. 2011). Antibody genes were cloned into the pET28a expression vector under the control of a $\mathrm{T} 7$ promoter and the resulting plasmids were transformed into $E$. coli BL21(DE3) cells. We have performed a comparative functional and structural analysis of the same trimerbody produced in E. coli or in mammalian cells, showing the functional equivalence of the two preparations. Our results demonstrate that $E$. coli is a viable alternative expression system for scFv-based $\mathrm{N}$-terminal trimerbody molecules.

\section{Methods}

\section{Reagents and antibodies}

Mouse IgG1 Tetra-His mAb specific for His-tagged proteins was from Qiagen $\mathrm{GmbH}$ (Hilden, Germany). The polyclonal antibodies included: horseradish peroxidase (HRP)-conjugated goat anti-mouse IgG, Fc specific, (Sigma-Aldrich, San Louis, MO, USA), and IRDye800conjugated donkey anti-mouse IgG (H\&L) (Rockland Immunochemicals, Gilbertsville, PA, USA). Laminin-111 (LM-111) extracted from the Engelbreth-Holm-Swarm (EHS) mouse tumor was from Invitrogen Life Technologies (Carlsbad, CA, USA), bovine serum albumin (BSA) and isopropyl-1-thio-b-D-galactoside (IPTG) were from Sigma-Aldrich, and human vascular endothelial growth factor $165\left(\mathrm{VEGF}_{165}\right)$ was from Peprotech (London, UK).

\section{Construction of expression vectors}

The mammalian expression vector pCR3.1-L36-hNC1encoding the anti-LM-111 L36 scFv-based N-terminal trimerbody, containing a murine $\mathrm{TIE}^{\mathrm{XVIII}}$ domain, has been previously reported (Blanco-Toribio et al. 2013). To generate the E.coli expression vector pET28a-L36, a 841-bp HindIII/NotI fragment of plasmid pHEN2L36 (Sanz et al. 2001, 2003), containing the the pectate lyase signal peptide (pelB) of Erwinia carotovora and the L36 scFv sequence, was cloned into the HindIII/NotI digested backbone of plasmid pET28a (Novagen, San Diego, CA, USA). To construct the plasmid pET28aL36-TIE, a human TIE ${ }^{\mathrm{XVIII}}$ domain of was synthesized by GeneartAG (Life Technologies) and subcloned as NotI/BamHI into the vector pET28a-L36. To generate the E.coli expression plasmid pET28a-2H1-TIE, the DNA fragment coding for the anti-VEGF $2 \mathrm{H} 1 \mathrm{scFv}$ (Lamdan et al. 2011) was synthesized by GeneArt AG and subcloned as Sfi/NotI into the vector pET28a-L36-TIE.

\section{Culture conditions and expression in bacteria}

E. coli BL21 cells [F-ompT hsdSB $\left(\mathrm{rB}^{-}, \mathrm{mB}^{-}\right)$gal dcm (DE3)] (Novagen) were transformed with T7 promoter driven expression vectors (pET28a). Bacteria were grown at $37^{\circ} \mathrm{C}$ in LB-agar plates or in liquid $2 x Y T$ medium, supplemented with appropriated antibiotics [ampicillin (Ap), $100 \mu \mathrm{g} / \mathrm{ml}$; kanamycin $(\mathrm{Km}), 35 \mu \mathrm{g} / \mathrm{ml}$. For periplasm expression, $20 \mathrm{ml} 2 \mathrm{xYT}$ cultures were grown overnight at $37^{\circ} \mathrm{C}$ under static culture conditions. The next day, the cultures were inoculated in an appropriate volume of $2 \mathrm{xYT}$ and incubated at $37^{\circ} \mathrm{C}$ and shaking at $250 \mathrm{rpm}$ until OD600 $=0.5$, IPTG was added to a final concentration of $0.1 \mathrm{mM}$ and then cultures were incubated for $20 \mathrm{~h}$ at $25^{\circ} \mathrm{C}$ and $180 \mathrm{rpm}$. Then cultures were centrifuged at $4,000 \mathrm{~g}$ for $10 \mathrm{~min}$ at $4^{\circ} \mathrm{C}$, and the pellets were resuspended in $1 / 20$ of the initial culture volume of precooled periplasmic preparation buffer $30 \mathrm{mM}$ Tris- $\mathrm{HCl}, \mathrm{pH}$ 8.0, $1 \mathrm{mM}$ EDTA, $20 \%$ sucrose. After a $20 \mathrm{~min}$ incubation on ice, bacteria were harvested by centrifugation at $6,000 \mathrm{~g}$ for $10 \mathrm{~min}$ at $4^{\circ} \mathrm{C}$. The supernatant was stored at $4^{\circ} \mathrm{C}$ and the pellets were resuspended in $1 / 20$ of initial culture volume of precooled $5 \mathrm{mM} \mathrm{MgSO}_{4}$, incubated for $20 \mathrm{~min}$ on ice and centrifuged for $10 \mathrm{~min}$ at $4^{\circ} \mathrm{C}$. After 20 min incubation on ice, bacteria were harvested by centrifugation at $6,000 \mathrm{~g}$ for $10 \mathrm{~min}$ at $4^{\circ} \mathrm{C}$. The two fractions were pooled, cleared by centrifugation at $30,000 \mathrm{~g}$ for 20 min, and dialyzed (cut-off 10,000 Da) against PBS pH 7.4. Antibody expression was analyzed using ELISA and western blotting. 


\section{Culture conditions and expression in mammalian cells} HEK-293 cells (CRL-1573; American Type Culture Collection, Rockville, MD, USA) were cultured in Dulbecco's modified Eagle's medium (DMEM) (Lonza, Walkersville, MD, USA) supplemented with $10 \%$ (vol/vol) heat inactivated fetal calf serum (FCS) (Invitrogen Life Technologies), unless otherwise stated. HEK-293 cells were transfected with the appropriate expression vectors using calcium phosphate (Compte et al. 2007). Stable cell lines were generated in HEK 293 cells and selected in DMEM with $0.5 \mathrm{mg} / \mathrm{ml} \mathrm{G-418} \mathrm{(Sigma-Aldrich),} \mathrm{and} \mathrm{the} \mathrm{proteins}$ were purified from conditioned medium with $0.1 \%$ (vol/ vol) FCS. Antibody expression was analyzed using ELISA and western blotting.

\section{Protein purification}

Harvested conditioned mammalian medium was centrifuged, $0.22 \mu \mathrm{m}$ filtered (Nalgene, Neerijse, Belgium), concentrated $(10 \times)$ with a 10.000 MWCO Vivaflow 50 filter (Vivascience $\mathrm{GmbH}$, Hannover, Germany), dialyzed against PBS (pH 7.4) and loaded onto a HisTrap HP $1 \mathrm{ml}$ column using and ÄKTA Prime plus system (GE Healthcare, Uppsala, Sweden). Dialyzed periplasmic preparations were $0.22 \mu \mathrm{m}$ filtered and loaded onto a HisTrap HP $1 \mathrm{ml}$ column using and ÄKTA Prime plus system. The purified antibodies were dialyzed against PBS, analyzed by SDSPAGE under reducing conditions and stored at $-80^{\circ} \mathrm{C}$.

\section{Western blotting}

Samples were separated under reducing conditions on $12 \%$ Tris-Glycine gels (Bio-Rad Laboratories Ltd., Hercules, CA, USA) and transferred using iBlot system (Invitrogen Life Technologies). After blocking with LI-COR blocking solution (LI-COR, Lincoln, NE, USA), proteins were detected with anti-His $\mathrm{mAb}$, followed by incubation with an IRDye800 conjugated donkey anti-mouse IgG. Images were taken using the Odyssey Infrared Imaging system (LI-COR).

\section{ELISA}

The ability of scFvs and scFv-based N-trimerbodies to bind LM-111 or VEGF 165 was studied by ELISA as described (Cuesta et al. 2009). Briefly, Maxisorp plates (NuncA/S, Roskilde, Denmark) were coated with LM-111 $(0.5 \mu \mathrm{g} /$ well $)$ or $\mathrm{VEGF}_{165}(0.3 \mu \mathrm{g} /$ well $)$ and after washing and blocking with $200 \mu \mathrm{l} 5 \%$ BSA in PBS, $100 \mu \mathrm{l}$ with indicated amount of purified protein or periplasmic extract were added for $1 \mathrm{~h}$ at room temperature. Antigen titration was performed with serial dilutions of purified L36 scFv-based trimerbodies, and after three washes, $100 \mu \mathrm{l}$ of HRP-conjugated protein A $(1 \mu \mathrm{g} / \mathrm{ml})$ were added for $1 \mathrm{~h}$ at room temperature, after which the plate developed with OPD.

\section{Serum stability}

One microgram of each purified $\mathrm{scFv}$-based $\mathrm{N}$-trimerbody was incubated in $60 \%$ human serum at $37^{\circ} \mathrm{C}$ for up to $96 \mathrm{~h}$. Samples were removed for analysis at 3, 24, 48 and $96 \mathrm{~h}$ and frozen at $-80^{\circ} \mathrm{C}$ until the entire study was completed. As a control, a second set of serum-exposed samples was frozen immediately to represent a zero time point. Aliquots of the different time-points samples were tested for their capability to bind LM-111 by ELISA.

\section{Size exclusion chromatography-multi-angle laser light scattering (SEC-MALLS)}

Static light scattering experiments were performed at room temperature using a Superdex 200 G10/300 GL Size Exclusion Chromatography column (GE HealthCare, Little Chalfont, United Kingdom) attached inline to a DAWN-HELEOS light scattering detector and an Optilab rEX differential refractive index detector (Wyatt Technology Corporation, Santa Barbara, CA, USA). The column was equilibrated with running buffer (PBS $+0.03 \% \mathrm{NaN}_{3}, 0.1 \mu \mathrm{m}$ filtered) and the SECMALLS system was calibrated with a sample of BSA at $1 \mathrm{mg} / \mathrm{ml}$. Then $100 \mu \mathrm{l}$ samples of the different antibodies at $0.3 \mathrm{mg} / \mathrm{ml}$ in PBS were injected into the column at a flow rate of $0.5 \mathrm{ml} / \mathrm{min}$. Data acquisition and analysis were carried out using ASTRA software (v 5.3.4.19, Wyatt). Based on numerous measurements on BSA samples at $1 \mathrm{mg} / \mathrm{ml}$ under the same or similar conditions we estimated that the experimental error in the molar mass is around $5 \%$.

\section{Results}

Production of scFv-based $\mathrm{N}$-terminal trimerbodies in the bacterial periplasm

The L36 scFv and the L36 scFv-based N-terminal trimerbody $\left(\right.$ L36 $\left.{ }^{\mathrm{N}}\right)$ were chosen as models (Fig. 1) and cloned into plasmid pET28a which contains a T7 promoter (Studier et al. 1990). Both plasmids were transformed into E. coli BL21(DE3) cells. The induction of antibody expression was achieved with a combination of low temperature, reduced IPTG concentration $(0.1 \mathrm{mM})$ and long induction times, and the presence and functionality of L36 $\mathrm{scFv}$ and $\mathrm{L} 36^{\mathrm{N}}$ in the periplasmic fraction was studied by western blot and ELISA. Both constructs were secreted as soluble proteins to the periplasm of $E$. coli BL21(DE3) cells (Fig. 2a). Western blot analysis, under reducing conditions, demonstrated that $\mathrm{L} 36 \mathrm{scFv}$ and L $36^{\mathrm{N}}$ trimerbody were single-chain type molecules with a migration pattern consistent with molecular weights calculated from their amino acid sequences (29.0 and $37.5 \mathrm{kDa}$, respectively) (Fig. 2a). Secreted L36 scFv and L36 ${ }^{\mathrm{N}}$ trimerbody specifically bound to immobilized human LM-111 (Fig. 2b). 

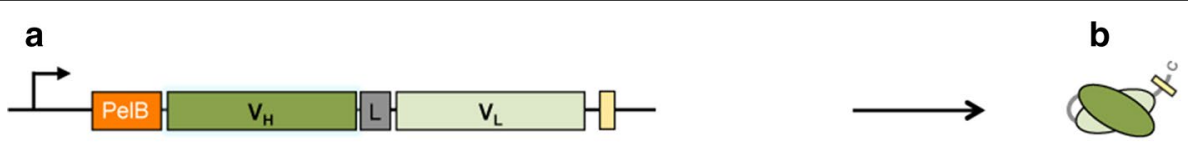

ScFv
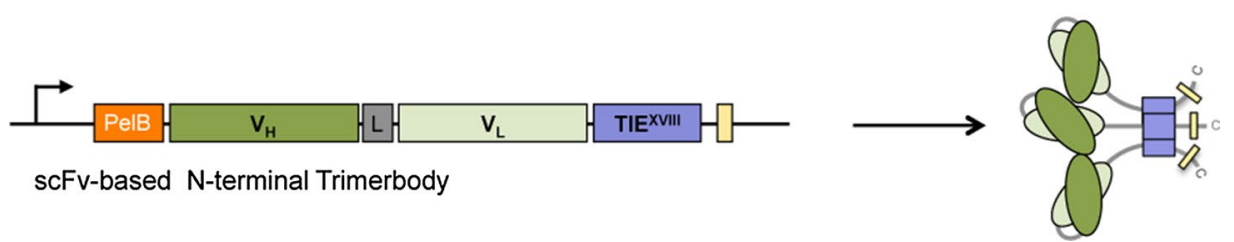

Fig. 1 a Schematic diagram of the scFv and the scFv-based N-terminal trimerbody gene constructs. Both constructs carry a N-terminal pelB signal sequence for potential periplasmic localization, the anti-laminin $L 36 \mathrm{scFv}$ gene ( $V_{H}$ and $V_{L}$ domains joined by a flexible linker), and $C$-terminal tags for immunodetection and purification (yellow box). The trimerbody gene constructs contains a TIEXVII domain. $\mathbf{b}$ Illustration showing the arrangement of $\mathrm{V}_{H}$ and $\mathrm{V}_{\mathrm{L}}$ domains in monomeric sCFV and of $\mathrm{V}_{H}, \mathrm{~V}_{\mathrm{L}}$ and $\mathrm{TI} \mathrm{E}^{\mathrm{XVIII}}$ domains in the trimerbody.

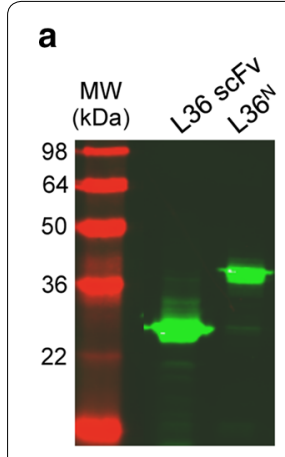

b

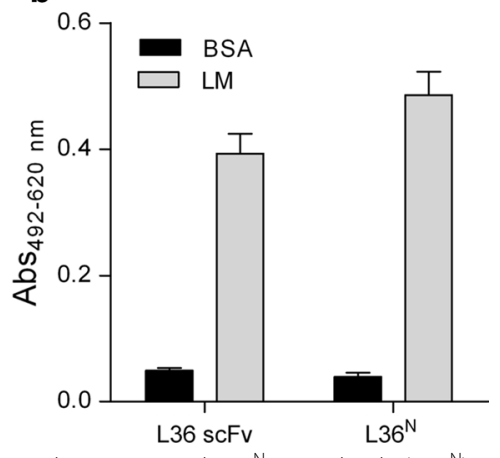

Fig. 2 Secretion of functional $L 36 \mathrm{scFv}$ and $L 36^{\mathrm{N}}$ trimerbody $\left(\mathrm{L} 36^{\mathrm{N}}\right)$ into the bacterial periplasmic. a Western blot profile of antibodies expressed in the periplasm of E. coli BL21(DE3) cells under induction with $0.1 \mathrm{mM}$ IPTG. b ELISA against plastic immobilized laminin-111.

\section{Purification and characterization of bacterially and mammalian-produced scFv-based $\mathrm{N}$-terminal trimerbodies}

For purification, the periplasmic fraction from transformed E. coli BL21(DE3) cells and the serum-free conditioned media from stably transfected HEK-293 cells were independently collected. Both $\mathrm{L} 6^{\mathrm{N}}$ trimerbodies were purified by immobilized metal affinity chromatography, which yielded $>95 \%$ pure proteins as assessed by reducing SDS-PAGE (Fig. 3a). The production yield of mammalian-and bacterially-produced $\mathrm{L} 36^{\mathrm{N}}$ trimerbodies after purification were about $1 \mathrm{mg} / \mathrm{l}$ and $7 \mathrm{mg} / \mathrm{l}$, respectively. The $\mathrm{L} 36^{\mathrm{N}}$ produced in $E$. coli was slightly smaller than that produced in mammalian cells, which could be attributed to differences in the lengths and amino acid compositions of the affinity tags: pCR3.1 mammalian expression plasmid contains the myc epitope and a sixhistidine tag (Sánchez-Arevalo Lobo et al. 2006), whereas
pET28a bacterial expression plasmid contains only a sixhistidine tag.

The trimeric nature of the $\mathrm{L} 36^{\mathrm{N}}$ molecules was confirmed by SEC-MALLS measurements. The sample of L36 ${ }^{\mathrm{N}}$ from HEK-293 cells eluted from the size exclusion column as a major symmetric peak at $12.8 \mathrm{ml}$ (Fig. 3b), with a small portion of high molecular weight aggregates eluting at the exclusion volume of the column. The mass derived from the dispersed light at the center of the peak is $121 \mathrm{kDa}$, a little higher than expected (117 kDa for the trimer). The sample of $\mathrm{L}^{3} 6^{\mathrm{N}}$ from $E$. coli produced a similar chromatogram with single peak at $13.4 \mathrm{ml}$ with a measured mass of $112 \mathrm{kDa}$ at its center as predicted for a trimer (Fig. 3c). Both measured molar masses are, within the experimental error, the same as the calculated values for trimeric molecules, indicating that they are indeed trimers in solution.

To avoid potential effects associated with the different tags used in both $\mathrm{L} 36^{\mathrm{N}}$ trimerbodies (myc-His tag in L36 ${ }^{\mathrm{N}}$ produced in HEK-293 and His tag in $\mathrm{L} 36^{\mathrm{N}}$ produced in E. coli), and given that the $\mathrm{L} 36 \mathrm{scFv}\left(\mathrm{V}_{\mathrm{H}} 3-\mathrm{DP} 47\right)$ binds to protein A (Sanz et al. 2001), LM-111 bound $\mathrm{L} 36^{\mathrm{N}}$ trimerbodies were developed with HRP-conjugated protein A. As shown in Fig. 3d, the binding curves of purified bacterially or mammalian-produced $\mathrm{L} 36^{\mathrm{N}}$ molecules to plastic immobilized human LM-111 were dose-dependent and saturable. The serum stability of both $\mathrm{L} 36^{\mathrm{N}}$ trimerbodies was studied by incubating each of the purified antibodies in human serum at $37^{\circ} \mathrm{C}$, for prolonged periods of time. Bacterially and mammalian-produced $\mathrm{L}^{2} 6^{\mathrm{N}}$ molecules had similar stability, retaining more than $95 \%$ of the initial LM111-binding activity after $96 \mathrm{~h}$ incubation (Fig. 3e).

To further validate the periplasmic expression systems for the secretion of trimerbody molecules, the antiVEGF $_{165} 2 \mathrm{H} 1$ scFv-based N-terminal trimerbody $\left(2 \mathrm{H} 1^{\mathrm{N}}\right)$ 


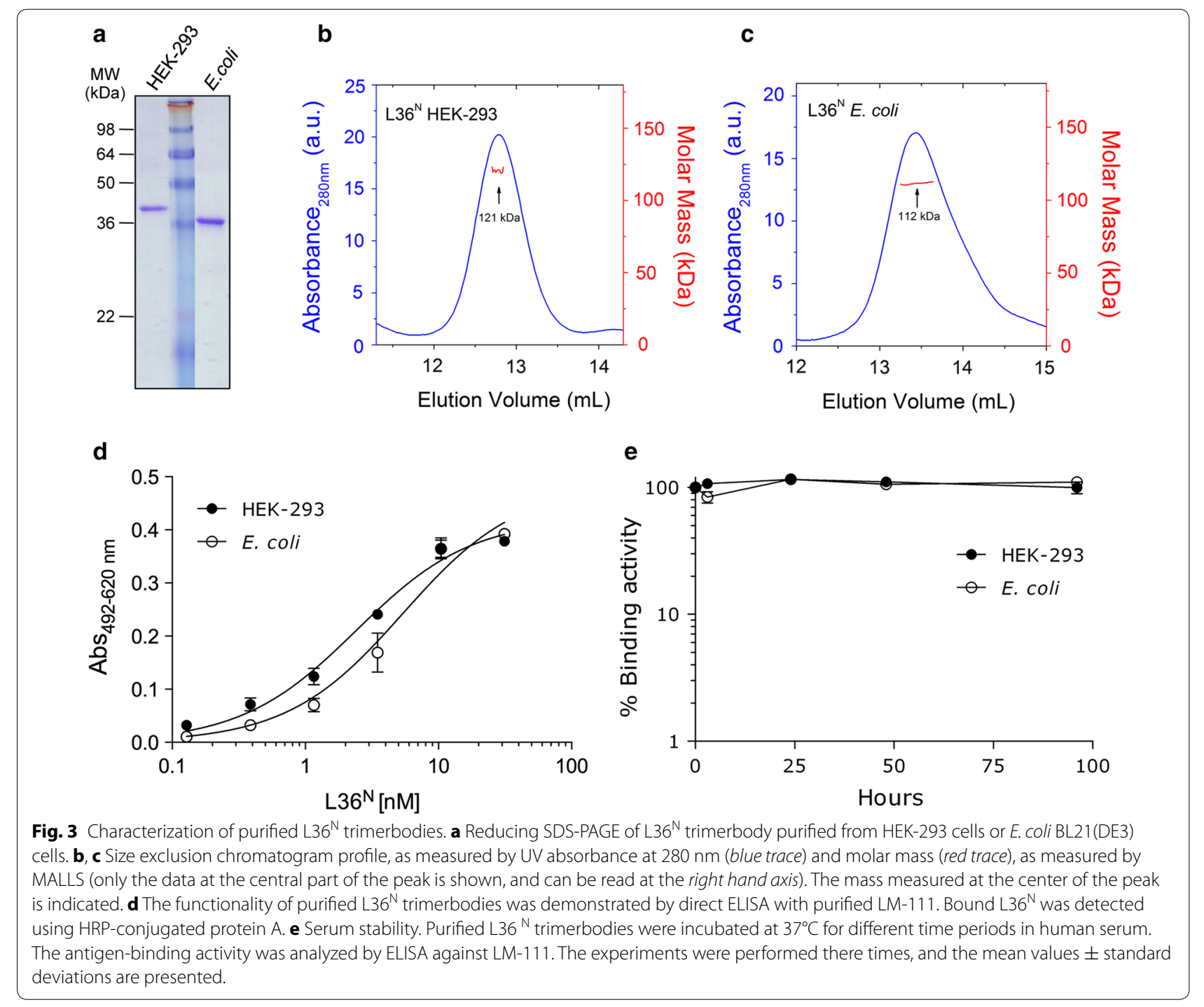

was cloned into the pET28a plasmid. Western blot analysis under reducing conditions of periplasm extracts showed that the migration pattern of secreted $\mathrm{L} 36^{\mathrm{N}}$ and $2 \mathrm{H} 1^{\mathrm{N}}$ was consistent with the molecular weight calculated from the polypeptide sequences (Fig. 4a). Functional analysis showed that the $2 \mathrm{H} 1{ }^{\mathrm{N}}$ trimerbody was able to bind specifically to immobilized human VEGF $_{165}$ (Fig. 4b).

\section{Discussion}

In the present study we demonstrate that functional scFvbased $\mathrm{N}$-terminal trimerbody molecules are expressed and secreted in E. coli at significant levels (about sevenfold higher than in mammalian cells). Moreover, we demonstrate that both bacterially and mammalian-produced

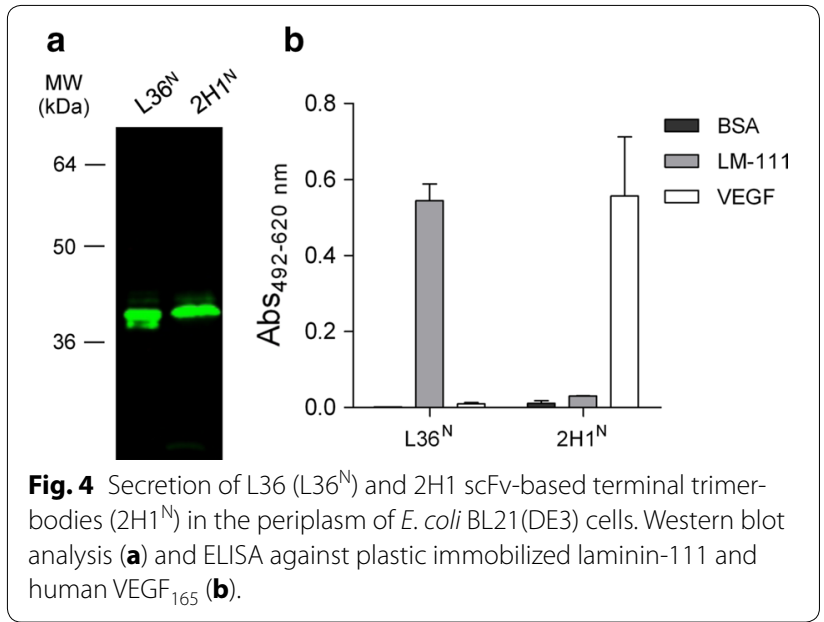


trimerbodies have similar functional and structural properties. Purified anti-LM-111 L36 ${ }^{\mathrm{N}}$ trimerbodies were trimeric in solution, as unambiguously shown by the light scattering measurements. L36 $^{\mathrm{N}}$ trimerbodies produced in E. coli BL21(DE3) cells or in HEK-293 cells are both highly efficient at antigen recognition. Stability at physiological temperatures and resistance to serum proteases are critical parameters for effective therapeutic application of recombinant antibodies (Willuda et al. 1999). In this study, we have shown that bacterially-produced L36 ${ }^{\mathrm{N}}$ trimerbodies are remarkably stable in human serum.

E. coli is one of the most important production system for recombinant proteins, amenable to high cell density fermentation in bioreactors and with high yields; however, multimeric antibodies are not ideal for expression in $E$. coli as they are made from different polypeptides, which must be exported into the periplasm to be folded properly and form the appropriate disulfide bonds (de Marco 2009; Sato and Inaba 2012). An additional relevant feature is the absence of protein glycosylation machinery in prokaryotic organisms, which is important for IgGmediated effector functions, but not for novel Fc-less engineered antibody formats, such as trimerbodies. The prediction of potential glycosylation sites using the GlycoEP server (Chauhan et al. 2013) showed that the L36 ${ }^{\mathrm{N}}$ and $2 \mathrm{H} 1^{\mathrm{N}}$ trimerbodies do not contain putative $\mathrm{N}$ - and $\mathrm{O}$-glycosylation sites, which prompted us to investigate E. coli-based expression systems for the production of scFv-based trimerbodies.

In recent years, considerable effort has been devoted to the optimization of bacterial expression systems for antibody production (Gershenson and Gierasch 2011). Bacteria have been widely used in the expression of recombinant antibodies (Spadiut et al. 2014), such as full-length IgG antibodies (Mazor et al. 2007; Chan et al. 2010), scFvs (Kipriyanov et al. 1997), Fab fragments (Wiebe et al. 2010), multimeric single-domain antibodies (Wang et al. 2013), multimeric Fabs (Hutchins et al. 2011), and multimeric scFvs (Powers et al. 2012) including trivalent antibodies made by fusing the trimerizing foldon domain from bacteriophage T4 fibritin to the C-terminus of a scFv fragment (Turki et al. 2014). Several strategies have been developed for the trimerization of $\mathrm{scFv}$ in order to increase avidity (Nuñez-Prado et al. 2015). Trimerbodies are engineered homotrimeric antibodies based on the use of the $\mathrm{N}$-terminal trimerization region of human collagen XV or XVIII NC1 domains, as trimerizing scaffolds. So far, scFv-based $\mathrm{N}$-terminal trimerbodies have only been produced in eukaryotic systems (Sánchez-Arevalo Lobo et al. 2006; Blanco-Toribio et al. 2014). Here, we have demonstrated that $E$. coli may be a promising and convenient expression system to produce more affordable functional anti-angiogenic scFv-based
$\mathrm{N}$-terminal trimerbodies for diagnostic and therapeutic applications.

\section{Author details}

${ }^{1}$ Department of Antibody Engineering, Leadartis S.L., Madrid, Spain. ${ }^{2}$ Molecular Immunology Unit, Hospital Universitario Puerta de Hierro, Majadahonda, Madrid, Spain. ${ }^{3}$ Structural Biology Unit, CIC bioGUNE, Parque Tecnológico de Bizkaia, Derio, Spain. ${ }^{4}$ IKERBASQUE, Basque Foundation for Science, Bilbao, Spain. ${ }^{5}$ Immunotherapy and Cell Engineering Laboratory, Department of Engineering, Aarhus University, Gustav Wieds Vej, 8000 Aarhus, Denmark.

\section{Acknowledgements}

L.S. was supported by grants from the Fondo de Investigación Sanitaria/Instituto de Salud Carlos III (PI13/00090) and the Comunidad de Madrid (S2010/ BMD-2312). F.J.B. was supported by a grant from Ministerio de Economía y Competitividad (CTQ2011-28680). A.B-T. was supported by Programa Torres Quevedo from Ministerio de Economía y Competitividad, cofounded by the European Social Fund (PTQ11-04604).

\section{Compliance with ethical guidelines}

\section{Competing interests}

The authors declare that they have no competing interests.

Received: 22 May 2015 Accepted: 27 July 2015

Published online: 04 August 2015

\section{References}

Baneyx F (1999) Recombinant protein expression in Escherichia coli. Curr Opin Biotechnol 10:411-421

Blanco-Toribio A, Sainz-Pastor N, Álvarez-Cienfuegos A, Merino N, Cuesta ÁM, Sánchez-Martín D et al (2013) Generation and characterization of monospecific and bispecific hexavalent trimerbodies. mAbs 5:70-79. doi:10.4161/mabs.22698

Blanco-Toribio A, Lacadena J, Nuñez-Prado N, Álvarez-Cienfuegos A, Villate M, Compte $M$ et al (2014) Efficient production of single-chain fragment variable-based N-terminal trimerbodies in Pichia pastoris. Microb Cell Fact 13:116. doi:10.1186/s12934-014-0116-1

Chan CEZ, Lim APC, Chan AHY, MacAry PA, Hanson BJ (2010) Optimized Expression of Full-Length IgG1 Antibody in a Common E. coli Strain. PLoS One 5:e10261. doi:10.1371/journal.pone.0010261

Chauhan JS, Rao A, Raghava GPS (2013) In silico Platform for Prediction of N-, O- and C-Glycosites in Eukaryotic Protein Sequences. PLoS One 8:e67008. doi:10.1371/journal.pone.0067008

Compte M, Blanco B, Serrano F, Cuesta AM, Sanz L, Bernad A et al (2007) Inhibition of tumor growth in vivo by in situ secretion of bispecific anti-CEA [times] anti-CD3 diabodies from lentivirally transduced human lymphocytes. Cancer Gene Ther 14:380-388. doi:10.1038/ sj.cgt.7701021

Cuesta ÁM, Sánchez-Martín D, Sanz L, Bonet J, Compte M, Kremer L et al (2009) In vivo tumor targeting and imaging with engineered trivalent antibody fragments containing collagen-derived sequences. PLoS One. doi:10.1371/journal.pone.0005381

Cuesta AM, Sainz-Pastor N, Bonet J, Oliva B, Alvarez-Vallina L (2010) Multivalent antibodies: when design surpasses evolution. Trends Biotechnol 28:355-362. doi:10.1016/j.tibtech.2010.03.007

Cuesta AM, Sánchez-Martín D, Blanco-Toribio A, Villate M, Enciso-Álvarez K, Alvarez-Cienfuegos A et al (2012) Improved stability of multivalent antibodies containing the human collagen XV trimerization domain. mAbs 4:226-232. doi:10.4161/mabs.4.2.19140

de Marco A (2009) Strategies for successful recombinant expression of disulfide bond-dependent proteins in Escherichia coli. Microb Cell Fact 8:26. doi:10.1186/1475-2859-8-26

Frenzel A, Hust M, Schirrmann T (2013) Expression of recombinant antibodies. Front Immunol. doi:10.3389/fimmu.2013.00217

Gershenson A, Gierasch LM (2011) Protein folding in the cell: challenges and progress. Curr Opin Struct Biol 21:32-41. doi:10.1016/j.sbi.2010.11.001 
Huang C-J, Lin H, Yang X (2012) Industrial production of recombinant therapeutics in Escherichia coli and its recent advancements. J Ind Microbio Biotechnol 39:383-399. doi:10.1007/s10295-011-1082-9

Hutchins BM, Kazane SA, Staflin K, Forsyth JS, Felding-Habermann B, Schultz PG et al (2011) Site-specific coupling and sterically controlled formation of multimeric antibody fab fragments with unnatural amino acids. J Mol Biol 406:595-603. doi:10.1016/j.jmb.2011.01.011

Kipriyanov SM, Moldenhauer G, Little M (1997) High level production of soluble single chain antibodies in small-scale Escherichia coli cultures. J Immunol Methods 200:69-77. doi:10.1016/S0022-1759(96)00188-3

Lamdan H, Ayala M, Rojas G, Munoz Y, Morera Y, Guirola O et al (2011) Isolation of a novel neutralizing antibody fragment against human vascular endothelial growth factor from a phage-displayed human antibody repertoire using an epitope disturbing strategy. J Biotechnol 151:166-174. doi:10.1016/j.jbiotec.2010.12.007

Leavy O (2010) Therapeutic antibodies: past, present and future. Nat Rev Immunol 10:297. doi:10.1038/nri2763

Makino T, Skretas G, Georgiou G (2011) Strain engineering for improved expression of recombinant proteins in bacteria. Microb Cell Fact 10:32. doi:10.1186/1475-2859-10-32

Mazor Y, Van Blarcom T, Mabry R, Iverson BL, Georgiou G (2007) Isolation of engineered, full-length antibodies from libraries expressed in Escherichia coli. Nat Biotechnol 25:563-565. doi:10.1038/nbt1296

Nuñez-Prado N, Compte M, Harwood S, Álvarez-Méndez A, Lykkemark S, Sanz $L$ et al (2015) The coming of age of engineered multivalent antibodies. Drug Discov Today. doi:10.1016/j.drudis.2015.02.013

Overton TW (2014) Recombinant protein production in bacterial hosts. Drug Discov Today 19:590-601. doi:10.1016/j.drudis.2013.11.008

Powers GA, Hudson PJ, Wheatcroft MP (2012) Design and production of multimeric antibody fragments, focused on diabodies with enhanced clinical efficacy. Methods Mol Biol 907:699-712. doi:10.1007/978-1-61779-974-7_39

Reichert JM (2014) Antibodies to watch in 2014. mAbs 6:799-802. doi:10.4161/ mabs.29282

Sánchez-Arevalo Lobo VJ, Cuesta AM, Sanz L, Compte M, García P, Prieto J et al (2006) Enhanced antiangiogenic therapy with antibody-collagen XVIII NC1 domain fusion proteins engineered to exploit matrix remodeling events. Int J Cancer 119:455-462. doi:10.1002/ijc.21851
Sanz L, Kristensen P, Russell SJ, Ramirez García JR, Alvarez-Vallina L (2001) Generation and characterization of recombinant human antibodies specific for native laminin epitopes: potential application in cancer therapy. Cancer Immunol Immunother 50:557-565. doi:10.1007/s00262-001-0235-5

Sanz L, Kristensen P, Blanco B, Facteau S, Russell SJ, Winter G et al (2002) Singlechain antibody-based gene therapy: inhibition of tumor growth by in situ production of phage-derived human antibody fragments blocking functionally active sites of cell-associated matrices. Gene Ther 9:1049-1053. doi:10.1038/sj.gt.3301725

Sanz L, García-Bermejo L, Blanco FJ, Kristensen P, Feijóo M, Suárez E et al (2003) A novel cell binding site in the coiled-coil domain of laminin involved in capillary morphogenesis. EMBO J 22:1508-1517. doi:10.1093/emboj/ cdg150

Sato Y, Inaba K (2012) Disulfide bond formation network in the three biological kingdoms, bacteria, fungi and mammals. FEBS J 279:2262-2271. doi:10.1111/j.1742-4658.2012.08593.x

Spadiut O, Capone S, Krainer F, Glieder A, Herwig C (2014) Microbials for the production of monoclonal antibodies and antibody fragments. Trends Biotechnol 32:54-60. doi:10.1016/j.tibtech.2013.10.002

Studier FW, Rosenberg AH, Dunn JJ, Dubendorff JW (1990) Use of T7 RNA polymerase to direct expression of cloned genes. Meth Enzymol 185:60-89

Turki I, Hammami A, Kharmachi H, Mousli M (2014) Engineering of a recombinant trivalent single-chain variable fragment antibody directed against rabies virus glycoprotein $\mathrm{G}$ with improved neutralizing potency. Mol Immunol 57:66-73. doi:10.1016/j.molimm.2013.08.009

Wang L, Liu X, Zhu X, Wang L, Wang W, Liu C (2013) Generation of singledomain antibody multimers with three different self-associating peptides. Protein Eng Des Sel 26:417-423. doi:10.1093/protein/gzt011

Wiebe JC, Schüller C, Reiche JA, Kramer K, Skerra A, Hock B (2010) An expression system for the $E$. coli fermentation of recombinant antibody Fab fragments from mice and rabbits. J AOAC Int 93:80-88

Willuda J, Honegger A, Waibel R, Schubiger PA, Stahel R, Zangemeister-Wittke $U$ et al (1999) High thermal stability is essential for tumor targeting of antibody fragments engineering of a humanized anti-epithelial glycoprotein-2 (epithelial cell adhesion molecule) single-chain Fv fragment. Cancer Res 59:5758-5767

\section{Submit your manuscript to a SpringerOpen ${ }^{\circ}$ journal and benefit from:}

- Convenient online submission

- Rigorous peer review

- Immediate publication on acceptance

- Open access: articles freely available online

- High visibility within the field

- Retaining the copyright to your article

Submit your next manuscript at springeropen.com 